\title{
Kinerja Bidan Desa di Desa Tertinggal dalam Penggerakan Masyarakat Bidang Kesehatan di Kabupaten Garut Tahun 2018
}

\author{
Intan Rina Susilawati ${ }^{1}$, Tita Husnitawati Madjid ${ }^{2}$, Herry Herman ${ }^{3}$
}

\begin{abstract}
Abstrak
Cakupan program kesehatan khususnya KIA di Kabupaten Garut masih belum mencapai target, diantaranya adalah pertolongan persalinan oleh tenaga kesehatan, masih rendahnya partisipasi masyarakat terhadap pelayanan kesehatan Posyandu melalui penimbangan Balita (D/S) rata - rata setahun. Hal ini salah satunya disebabkan karena masih belum optimalnya peran dan fungsi bidan desa khususnya di desa tertinggal dalam menjalankan tugasnya sebagai penggerak masyarakat di bidang kesehatan. Penelitian ini bertujuan untuk menganalisis faktor - faktor yang berpengaruh terhadap kinerja bidan desa di desa tertinggal dalam penggerakan masyarakat di Kabupaten Garut. Penelitian ini menggunakan metode deskriptif dan analitik berbentuk studi korelasional dengan pendekatan cross sectional. Pengambilan sampel secara simple random sampling sebanyak 84 responden. Variabel independen terdiri dari faktor umur, pendidikan, lama kerja, pengetahuan, motivasi, imbalan/penghargaan. variabel terikatnya adalah kinerja bidan desa di desa tertinggal dalam penggerakan masyarakat di bidang kesehatan di Kabupaten Garut. Analisis data menggunakan chi square dan regresi logistik ganda. Hasil penelitian dengan analisis bivariabel menunjukan terdapat hubungan yang berpengaruh antara faktor umur (p 0,001) POR 2,31, pendidikan $(<0,001)$ POR 4,45, lama kerja $(<0,001)$ POR 2,54, pengetahuan $(\mathrm{p} 0,004)$ POR 2,03, motivasi $(\mathrm{p}<0,001)$ POR 6,05, penghargaan/imbalan $(\mathrm{p}<0,001)$ POR 3,81 dengan kinerja bidan desa di desa tertinggal dalam penggerakan masyarakat di bidang kesehatan di Kabupaten Garut. Hasil analisis multivariabel menunjukan secara simultan faktor yang berpengaruh terhadap kinerja bidan desa di desa tertinggal di Kabupaten Garut adalah faktor umur (p 0,010) OR 10,30, pendidikan ( $\mathrm{p}$ 0,014) OR 6,96, motivasi $(0,001)$ OR 21,87 dan penghargaan/imbalan $(\mathrm{p} 0,022)$ OR 5,91. Kesimpulan penelitian adalah kinerja bidan desa di desa tertinggal dalam penggerakan masyarakat di bidang kesehatan di Kabupaten Garut, memiliki kinerja tinggi sebesar 57,1\%. Terdapat hubungan antara faktor umur, tingkat pendidikan, lama kerja, pengetahuan, motivasi, penghargaan/imbalan dengan kinerja bidan desa di desa tertinggal dalam penggerakan masyarakat di bidang kesehatan di Kabupaten Garut. Faktor umur, tingkat pendidikan, motivasi dan penghargaan/imbalan berpengaruh terhadap kinerja bidan desa di desa tertinggal dalam penggerakan masyarakat di bidang kesehatan di Kabupaten Garut.
\end{abstract}

Kata Kunci: Kinerja, Bidan, Desa Tertinggal, Penggerakan Masyarakat

\section{Abstract}

The coverage of health programs, especially child and mother in Garut Regency still has not reached the target, such as the help of delivery by health provider, still low public participation on health services primary health care through weighing underfive $(D / S)$ average a year. This one of them is because it is still not optimalrole and function of midwife especially in disadvanted village in carrying out its dutyas mobilizer of society in health sector. This study aims to analyze the factors that affect the performance of midwives in the disadvanted village in the community mobilizer in Garut Regency. This research is a descriptive and analytic method in the form of correlation study with ross sectional approach. Sampling in simple random sampling was 84 respondents. The independent variable consist of age, education, length of work, knowledge, motivation, reward. The dependent variable is the performance of midwives in disadvanted villages in the mobilization of the community in the field of health in Garut Regency. Data analysis using 
chi square and multiple logistic regression. The results of bivariable analysis showed that there was a correlation between age factor (p 0.001) POR 2.31, education $(<0.001)$ POR 4.45, duration of work $(<0.001)$ POR 2.54, knowledge (p 0.004) POR 2,03, motivation $(P<0.001)$ POR 6,05, reward $(p<0,001)$ POR 3,81 with the performance of the midwives in the disadvanted villages in community mobilization in the health sector in Garut regency. The result of multivariable analysis showed that factors affecting the performance of village midwife in the disadvanted village in Garut regency were age factor $(p 0,010)$ OR 10,30, education $(p 0,014)$ OR 6,96, motivation $(0,001)$ OR 21,87 and reward (p 0.022) OR 5.91. The conclusion of this study is that the performance height of the midwives in the village in the community mobilization in the health sector in Garut disadvanted regency, has a high performance of $57.1 \%$. There is relationship between age factor, education level, length of work, knowledge, motivation, reward with performance of midwife in disadvanted village in community mobilization in health sector in Garut Regency. Factors correlated and performance in community mobilization are in descending order age, education level, motivation and reward.

Keywords: Performance, Midwives, Disadvanted Villages, Community Mobilization

\section{PENDAHULUAN}

Kesehatan merupakan hak asasi manusia dan salah satu unsur kesejahteraan yang harus diwujudkan sesuai dengan citacita bangsa Indonesia sebagaimana dimaksud dalam Pancasila sila ke lima dan UndangUndang Dasar Negara Republik Indonesia Tahun 1945 pasal 34 ayat 2 dan 3.

Secara umum permasalahan mendasar bagi pembangunan nasional bidang kesehatan sesuai amanah Konstitusi UUD 1945 dalam pemenuhan "Hak Dasar Sehat" dan UU No 36 tahun 2009 tentang Kesehatan, belum mampu merespon kebutuhan faktor dasar dan faktor penentu dasar kualitas kesehatan yang diukur dengan Indeks Angka Harapan Hidup, dimana $\mathrm{AHH}$ Indonesia lebih rendah dari $\mathrm{AHH}$ negara Vietnam. AHH di Daerah Tertinggal jauh lebih rendah lagi, dan hal ini membutuhkan kebijakan percepatan pembangunan kualitas kesehatan serta komitmen keberpihakan semua pihak yang dilaksanakan melalui rencana aksi yang terukur baik waktu, indikator sasaran dan target kinerja maupun sumber daya pembangunan yang proporsional dengan beban kerja di 183 Kabupaten Daerah Tertinggal, Terdepan, Terluar dan Pasca Konflik sebagai Prioritas Pembangunan Nasional, yang luasnya lebih dari setengan luas NKRI dan Karakteristik ketertinggalan berupa sulitnya jangkauan wilayah kerja, rendahnya ekonomi masyarakat, kurangnya infrastruktur, rendahnya kualitas SDM, rendahnya kapasitas lembaga daerah dan rendahnya keterjangkauan masyarakat terhadap pelayanan publik.

Bidang kesehatan merupakan unsur yang sangat penting dalam strategi pengembangan sumber daya manusia, untuk itu dalam jangka pendek prioritas di bidang kesehatan di Kabupaten Garut adalah meneruskan program-program kesehatan yang telah berhasil, mengurangi kematian bayi, 
anak balita dan ibu melahirkan, mengatasi kekurangan gizi, dan mengurangi penyakit menular.

Untuk mencapai tujuan pembangunan kesehatan tersebut diselenggarakan berbagai upaya kesehatan secara menyeluruh, berjenjang dan terpadu. Salah satu strateginya adalah dengan adanya kebijakan penempatan bidan desa dengan Surat Edaran Direktur Jenderal Pembinaan Kesehatan Masyarakat Nomor 429/Binkesmas/DJ/III.97tanggal 29 Maret 1997.

Pada tahun 2013, Kementerian Pengentasan Daerah Tertinggal telah melakukan identifikasi desa tertinggal di Kabupaten Garut sebagai upaya dalam menentukan lokasi pelaksanaan pengentasan daerah tertinggal. Hasil identifikasi memperlihatkan sebanyak 137 desa (32\%) merupakan desa tertinggal dari total 403 desa/kelurahan. Sebaran desa tertinggal tersebut adalah 24 desa di wilayah Garut Utara, 37 desa di wilayah Garut Tengah dan 76 desa di wilayah Garut Selatan. Desa tertinggal adalah kawasan pedesaan yang ketersediaan sarana dan prasarana dasar wilayahnya kurang/tidak ada (tertinggal) sehingga menghambat pertumbuhan/ perkembangan kehidupan masyarakatnya dalam bidang ekonomi (kemiskinan) dan bidang pendidikan (keterbelakangan).

Berdasarkan data dari Dinas Kesehatan Kabupaten Garut tahun 2016,
Kabupaten Garut telah memiliki 1.148 bidan yang tersebar di seluruh wilayah Kabupaten Garut. Sebanyak 431 orang merupakan bidan desa dan sisanya 717 orang bidan fungsional di puskesmas-puskesmas. Dilihat dari kuantitas bidan yang hampir dua kali lipat dari jumlah desa di Kabupaten Garut, capaian program khususnya program Kesehatan Ibu dan Anak (KIA) seharusnya sesuai dengan target yang diharapkan sebesar 90\%. Namun pada kenyataannya masih banyak capaian program KIA yang belum memenuhi target dan baru mencapai 78\%. Hal ini disebabkan karena kinerja bidan dalam hal penggerakkan masyarakat dibidang kesehatan masih kurang. Selain itu juga masih rendahnya kesadaran masyarakat dalam mendukung dan menjalankan program kesehatan. Contohnya masih rendahnya partisipasi masyarakat terhadap Posyandu melalui penimbangan Balita (D/S) rata-rata setahun $71,2 \%$ dari target $84 \%$. Hal ini disebabkan penggerakkan masyarakatnya yang masih belum dilakukan dengan baik.

Berdasarkan penjelasan dari Kepala Seksi (Kasie) KIA Dinas Kesehatan Kabupaten Garut, bahwa cakupan hasil pelayanan masih belum memenuhi pencapaian target $71,2 \%$ dari $84 \%$. Hal ini ada hubungannya dengan penurunan kinerja bidan di desa yang disebabkan oleh karakteristik pribadi bidan yang meliputi umur, minat serta lama kerja dan masih 
rendahnya motivasi kerja yang meliputi gaji, pengakuan, tanggungjawab, kondisi kerja serta supervisi. Selain itu juga faktor sosial budaya mayarakat setempat, kesadaran masyarakat tentang kesehatan yang masih rendah. Hal tersebut dapat terlihat dari rendahnya keterlibatan masyarakat dalam upaya kesehatan karena kurangnya peran petugas kesehatan dalam menggerakkan masyarakat. Dengan kata lain, kualitas bidan dan fungsi-fungsinya dalam menjalankan peran profesionalnya masih tidak sesuai dengan harapan.

Studi pendahuluan yang dilakukan peneliti pada awal November 2014 terhadap 8 orang bidan desa di desa tertinggal yang ada di wilayah kerja Dinas Kesehatan Kabupaten Garut. Peran dan fungsi bidan sebagai penggerak masyarakat di bidang kesehatan belum dapat dilakukan dengan optimal. Penyebabnya bermacam-macam, diantaranya adalah karena 1) bidan desa tidak tinggal di desa wilayah kerja, 2) bidannya sedang melanjutkan pendidikan, 3) lokasi antar rumah yang terpencar berjauhan dan keamanan lingkungan, 4) lokasi geografis yang sulit dijangkau kendaraan, 5) masyarakatnya sibuk dengan pekerjaannya di ladang dan sawah. Sehingga programprogram kesehatan masih belum mencapai target, contohnya kunjungan ke Posyandu masih di bawah target, masih adanya Balita dengan gizi buruk, pertolongan persalinan oleh tenaga kesehatan masih rendah karena masyarakat masih banyak yang bersalin ditolong oleh paraji.

Delapan orang bidan tersebut menyatakan sudah membuat rencana kegiatan/rencana program penggerakkan masyarakat agar cakupan program kesehatan ibu dan anak bisa tercapai sesuai target $84 \%$, sehingga dengan meningkatnya pelayanan kesehatan ibu dan anak (KIA), meningkatnya angka harapan hidup (AHH) 71\% pertahun, dan menurunnya angka kesakitan (Morbiditas), serta meningkatnya status gizi (gizi bayi yang diukur dengan berat badan lahir rendah (BBLR), status gizi ibu hamil, dan status gizi balita), maka derajat kesehatan masyarakat di Kabupaten Garut bisa meningkat. Selain itu juga adanya peningkatan peran serta masyarakat dalam berbagai program-program kesehatan, seperti: meningkatnya kesadaran masyarakat dalam pemanfaatan Posyandu, deteksi dini resiko tinggi ibu hamil (ibu bersalin, ibu nifas juga bayi baru lahir dan Balita), meningkatnya kesadaran masyarakat mengenai pentingnya pertolongan persalinan oleh tenaga kesehatan, pola hidup bersih (PHBS) dan segala sesuatu yang berhubungan dengan program-program kesehatan serta meningkatnya peranan penyuluhan kesehatan masyarakat (PKM). Menurut Kasie KIA Dinas Kesehatan Kabupaten Garut, kinerja bidan di desa tertinggal masih kurang terutama dalam hal 
penggeraan masyarakat, hal ini disebabkan karena bidan terlalu banyak mengerjakan tugas administrasi, diantaranya mengurus keuangan karena menjadi bendahara Jaminan Kesehatan Nasional (JKN) atau bendahara Bantuan Operasional Puskesmas (BOK), sehingga tugas, peran dan fungsi utamanya sebagai bidan desa terabaikan.

Keberhasilan cakupan program kesehatan tidak terlepas dari kinerja dan peran bidan desa dalam menggerakkan masyarakat. Kinerja bidan di desa dipengaruhi oleh: 1) faktor karakteristik individu bidan (usia, pendidikan, lama kerja, motivasi, kemampuan dan ketrampilan, latar belakang, dan demografi), 2) faktor lingkungan kerja (sumber daya, kepemimpinan, penghargaan/imbalan, struktur organisasi, dan beban kerja. Karakteristik individu bidan menunjukkan bahwa semakin lama bekerja dan semakin tua usia seseorang maka akan semakin banyak pengalaman yang didapatkan sehingga berpengaruh terhadap kemampuan (pengetahuan dan keterampilan) yang diperolehnya. Tugas utama seorang bidan sesuai dengan ketentuan yang diisyaratkan oleh organisasi Ikatan Bidan Indonesia (IBI) adalah melaksanakan pekerjaannya sesuai dengan standar kerja. Sedangkan psikologis merupakan merupakan salah satu faktor kepuasan dalam bekerja, hubungan tinggi dengan atasan dan karyawan lain. Tingkat kepuasan yang di dapat akan memperoleh motivasi kerja yang tinggi. Motivasi kerja merupakan kekuatan penting yang harus ada dalam diri bidan sehingga ia memiliki keinginan atau semangat yang kuat untuk berusaha dan bekerja keras sehingga akan diperoleh keberhasilan.

Berdasarkan latar belakang penelitian yang telah di uraian di atas, maka permasalahan dalam penelitian ini dapat dirumuskan sebagai berikut:

1. Bagaimana gambaran kinerja bidan desa di desa tertinggal dalam penggerakan masyarakat di bidang kesehatan di Kabupaten Garut?

2. Apakah terdapat hubungan faktor - faktor individu (umur, pendidikan, lama kerja, pengetahuan, motivasi) dan lingkungan (penghargaan/ imbalan) dengan kinerja bidan desa di desa tertinggal dalam penggerakan masyarakat di bidang kesehatan di Kabupaten Garut?

3. Apakah faktor yang berpengaruh terhadap kinerja bidan desa di desa tertinggal dalam penggerakan masyarakat di bidang kesehatan di Kabupaten Garut?

\section{METODE PENELITIAN}

Penelitian ini menggunakan metode deskriptif dan analitik berbentuk studi korelasional dengan pendekatan cross sectional. Pengambilan sampel secara simple random sampling sebanyak 84 responden. Variabel independen terdiri dari faktor umur, 
pendidikan, lama kerja, pengetahuan, motivasi, imbalan/ penghargaan. variabel terikatnya adalah kinerja bidan desa di desa tertinggal dalam penggerakan masyarakat di bidang kesehatan di Kabupaten Garut. Analisis data menggunakan chi square dan regresi logistik ganda.

\section{HASIL DAN PEMBAHASAN}

Berdasarkan penelitian didapatkan hasil sebagai berikut :

Tabel 1. Distribusi Frekuensi Kinerja Bidan Desa di Kabupaten Garut n=84

\begin{tabular}{ccc}
\hline Kinerja & F & \% \\
\hline Rendah & 36 & 42,9 \\
Tinggi & 48 & 57,1 \\
\hline Jumlah & 84 & 100 \\
\hline
\end{tabular}

Tabel 1. di atas menunjukkan data kinerja bidan desa di desa tertinggal dalam penggerakan masyarakat di bidang kesehatan di Kabupaten Garut, dari jumlah responden sebanyak 84 orang, kinerja rendah sebanyak 36 orang $(42,9 \% 0$ dan kinerja tinggi sebanyak 48 orang $(57,1 \%)$, dengan 95\% confident interval 46,5\% $67,2 \%$.

Tabel 2. Analisis Faktor - Faktor yang Berhubungan Dengan Kinerja Bidan Desa Di Desa Tertinggal Dalam Penggerakan Masyarakat di Bidang Kesehatan Di Kabupaten Garut

\begin{tabular}{|c|c|c|c|c|c|c|}
\hline \multirow{3}{*}{$\begin{array}{c}\text { Variebel } \\
\text { Bebas }\end{array}$} & \multicolumn{4}{|c|}{ Kinerja } & \multirow{3}{*}{ Nilai $p$} & \multirow{3}{*}{$\begin{array}{c}\text { POR } \\
95 \% \text { CI }\end{array}$} \\
\hline & \multicolumn{2}{|c|}{ Rendah } & \multicolumn{2}{|c|}{ Tinggi } & & \\
\hline & $n=36$ & $\%$ & $n=48$ & $\%$ & & \\
\hline \multicolumn{7}{|l|}{ Umur } \\
\hline$\overline{\leq 35}$ tahun & 24 & $61,5 \%$ & 15 & $38,5 \%$ & 0,001 & 2,31 \\
\hline$>35$ tahun & 12 & $26,7 \%$ & 33 & $73,3 \%$ & & $(1,34-3,98)$ \\
\hline Pendidikan & & & 9 & & $<0,001$ & \\
\hline$\overline{\text { D3 Kebidanan }}$ & 28 & $75,7 \%$ & 39 & $24,3 \%$ & & 4,45 \\
\hline \multirow[t]{2}{*}{ D4 Kebidanan } & 8 & $17,0 \%$ & & $83,0 \%$ & $<0,001$ & $(2.30-8,58)$ \\
\hline & & & 13 & & & \\
\hline Lama kerja & & & 35 & & 0,004 & \\
\hline$\leq 5$ tahun & 24 & $64,9 \%$ & & $35,1 \%$ & & 2,54 \\
\hline \multirow{2}{*}{$>5$ tahun } & 12 & $25,5 \%$ & & $74,5 \%$ & $<0,001$ & $(1,48-4,37)$ \\
\hline & & & 12 & & & \\
\hline Pengetahuan & & & 36 & & $<0,001$ & \\
\hline$\overline{\text { Rendah }}$ & 20 & $62,5 \%$ & & $37,5 \%$ & & 2,03 \\
\hline \multirow[t]{2}{*}{ Tinggi } & 16 & $30,8 \%$ & & $69,2 \%$ & & $(1,25-3,31)$ \\
\hline & & & 8 & & & \\
\hline Motivasi & & & 40 & & & \\
\hline$\overline{\text { Rendah }}$ & 30 & $78,9 \%$ & & $21,1 \%$ & & 6,05 \\
\hline Tinggi & 6 & $13,0 \%$ & 10 & $87,0 \%$ & & $(2,82-$ \\
\hline & & & 38 & & & $12,99)$ \\
\hline \multicolumn{7}{|l|}{ Imbalan } \\
\hline$\overline{\text { Rendah }}$ & 27 & $73,0 \%$ & & $27,0 \%$ & & \\
\hline
\end{tabular}




\begin{tabular}{|c|c|c|c|}
\hline Tinggi & $19,1 \%$ & $80,9 \%$ & $\begin{array}{c}3,81 \\
(2,05-7,08)\end{array}$ \\
\hline
\end{tabular}

Keterangan : POR (IK 95\%) : prevalens odds rasio dn interval kepercayaan 95\%

Tabel 2. menyajikan hasil analisis bivariabel hubungan dari faktor individu dan lingkungan dengan kinerja bidan desa di desa tertinggal dalam penggerakan masyarakat di bidang kesehatan di Kabupaten Garut. Dari tersebut tampak secara bivariabel semua variabel yang diteliti berhubungan dengan kinerja bidan desa di desa tertinggal. Makin tinggi usia, makin tinggi kinerja, makin tinggi tingkat pendidikan makin tinggi kinerja, makin lama masa kerja makin tinggi kinerja, makin tinggi pengetahuan makin tinggi kinerja, makin tinggi motivasi makin tinggi juga kinerja.

Selanjutnya, untuk menganalisis faktor - faktor yang berhubungan secara simultan dilakukan analisis regresi ganda, hasilnya seperti ditunjukkan di tabel 3.

Tabel 3. Analisis Multivariabel Hubungan Faktor Individu Dan Lingkungan Dengan Kinerja Berdasarkan Regresi Logistik Ganda

\begin{tabular}{|c|c|c|c|c|c|}
\hline No & Variabel & Koefisien B & SE (B) & Nilai $\mathbf{p}$ & OR adj (IK 95\%) \\
\hline \multirow[t]{8}{*}{ I. } & Model awal : & & & & \multirow{8}{*}{$\begin{array}{c}9,54 \\
(1,445-62,981) \\
5,73 \\
(1,029-31,863) \\
1,38 \\
(0,233-8,207) \\
2,07 \\
(0,425-10,032) \\
18,33 \\
(2,844-118,127) \\
5,12 \\
(1,073-24,457)\end{array}$} \\
\hline & Umur & 2,26 & 0,96 & 0,019 & \\
\hline & & & & & \\
\hline & Pendidikan & 1,75 & 0,88 & 0,046 & \\
\hline & Lama kerja & 0,32 & 0,91 & 0,721 & \\
\hline & Pengetahuan & 0,73 & 0,81 & 0,368 & \\
\hline & Motivasi & 2,91 & 0,95 & 0,002 & \\
\hline & Imbalan & 1,63 & 0,80 & 0,041 & \\
\hline \multirow{4}{*}{ II. } & $\begin{array}{l}\text { Model Akhir : } \\
\text { Umur }\end{array}$ & 2,33 & $0,0,90$ & 0,010 & \multirow{4}{*}{$\begin{array}{c}10,30 \\
(1,755-60,472) \\
6,96 \\
(1,469-32,956) \\
21,87 \\
(3,798-125,947) \\
5,91 \\
(1,297-26,928)\end{array}$} \\
\hline & Pendidikan & 1,94 & 0,79 & 0,014 & \\
\hline & Motivasi & 3,09 & 0,89 & 0,001 & \\
\hline & $\begin{array}{l}\text { Imbalan } \\
\text { Constant }=-4,748\end{array}$ & 1,78 & 77 & 0,022 & \\
\hline
\end{tabular}

Keterangan : OR (IK 95\%) : odds rasio dn interval kepercayaan 95\%

Dari hasil analisis regresi logistik ganda (tabel 3) diatas memperlihatkan bahwa hasil akhir analisis multivariabel, variabel yang masuk ke dalam model akhir adalah umur, pendidikan, motivasi dan penghargaan. 


\section{Uji Hipotesis}

Hasil uji statistik yang sudah dilakukan terhadap variabel penelitian bertujuan untuk membuktikan hipotesis.

\section{Hipotesis 1}

Terdapat hubungan antara (usia, pendidikan, lama bekerja, pengetahuan, motivasi, imbalan/penghargaan) dengan kinerja bidan desa di desa tertinggal dalam penggerakan masyarakat di bidang kesehatan di Kabupaten Garut.

Hal yang menunjang :

Berdasarkan perhitungan statistik menggunakan chi square menunjukkan terdapat hubungan antara faktor umur dengan kinerja bidan desa di desa tertinggal dalam penggerakan masyarakat di bidang kesehatan di Kabupaten Garut dengan nilai p 0,001, faktor pendidikan dengan nilai $\mathrm{p}<0,001$, faktor lama bekerja dengan nilai $\mathrm{p}<0,001$, faktor pengetahuan dengan nilai $\mathrm{p}$ 0,004, faktor motivasi dengan nilai $\mathrm{p}<0,001$, faktor imbalan dengan nilai $\mathrm{p}<0,001$.

Kesimpulan : Hipotesis 1 diterima.

\section{Hipotesis 2}

Faktor individu berpengaruh secara signifikan terhadap kinerja bidan desa di desa tertinggal dalam penggerakan masyarakat di bidang kesehatan di Kabupaten Garut.

Hal yang menunjang :

Berdasarkan analisis statistik menggunakan regresi logistik ganda menunjukkan faktor motivasi dominan berpengaruh signifikan ( $p$
0,001) dengan nilai OR 21,87, faktor umur ( $p$ 0,010) dengan nilai OR 10,30, faktor pendidikan ( $\mathrm{p}$ 0,014) dengan nilai OR 6,96 dan faktor imbalan (p 0,022) dengan nilai OR 5,91 .

Kesimpulan : Hipotesis 2 diterima

\section{Pembahasan}

a. Hubungan Umur Dengan Kinerja

Bidan Desa Di Desa Tertinggal Dalam Penggerakan Penggerakan Masyarakat di Bidang Kesehatan

Hasil penelitian ini menunjukkan bahwa faktor umur mempunyai nilai POR = 2,31 yang artinya risiko untuk kinerja bidan yang rendah pada kelompok umur $<35$ tahun adalah 2,31 kali lebih besar dibandingkan kelompok umur $>35$ tahun. Secara statistik hubungan ini bermakna dengan nilai $\mathrm{p}$ sebesar 0,001 pada tingkat kepercayaan 95\%.

Beberapa studi menyatakan bahwa umumnya pekerja berusia dewasa lebih stabil dan tetap produktif dibanding dengan rekan kerjanya yang lebih muda. Menurut penelitian Saimin, umur bidan yang masih muda, tidak tinggal di desa, kurangnya kessabaran dalam memberikan pelayanan, adalah merupakan faktor - faktor yang turut mempengaruhi rendahnya kepercayaan masyarakat kepada bidan.

b. Hubungan Pendidikan Dengan Kinerja Bidan Desa Di Desa Tertinggal Dalam Penggerakan Penggerakan Masyarakat di Bidang Kesehatan 
Hasil penelitian ini menunjukkan bahwa faktor pendidikan mempunyai nilai $\mathrm{POR}=$ 4,45 yang artinya risiko untuk kinerja bidan yang rendah pada kelompok pendidikan D3 kebidanan adalah 4,45 kali lebih besar dibandingkan kelompok pendidikan D4 Kebidanan. Secara statistik hubungan ini bermakna dengan nilai $\mathrm{p}$ sebesar $<0,001$ pada tingkat kepercayaan 95\%.

Menurut Crow \& Crow pendidikan adalah proses pengalaman yang memberikan pengertian, pandangan (insight) dan penyesuaian bagi seseorang yang menyebabkan ia dapat berkembang. ${ }^{6}$ Tingkat atau jenjang pendidikan adalah tahap pendidikan yang ditetapkan berkelanjutan, yang ditetapkan berdasarkan tingkat perkembangan peserta didik, tingkat kerumitan bahan pengajaran dan cara meyajikan pengajaran.

Penelitian yang dilakukan oleh Achmad dan Winarsih, menyatakan bahwa tingkat pendidikan sangat berpengaruh terhadap kinerja yang dijalankan seseorang.

\section{c. Hubungan Lama Kerja Dengan Kinerja}

Bidan Desa Di Desa Tertinggal Dalam Penggerakan Penggerakan Masyarakat di Bidang Kesehatan

Hasil penelitian ini menunjukkan bahwa faktor lama kerja mempunyai nilai POR = 2,54 yang artinya risiko untuk kinerja bidan yang rendah pada kelompok lama kerja $<5$ tahun adalah 2,54 kali lebih besar dibandingkan kelompok lama kerja $>5$ tahun. Secara statistik hubungan ini bermakna dengan nilai $\mathrm{p}$ sebesar $<0,001$ pada tingkat kepercayaan 95\%.

Lama kerja berhubungan dengan bekal yang sangat baik untuk memperbaiki keinerja seseorang. Lama kerja dapat menggambarkan pengalaman seseorang dalam menguasai bidang tugasnya. Green (1980), mengemukakan bahwa kinerja dapat dipengaruhi oleh faktor predisposisi yang di dalamnya termasuk pengalaman kerja. Pengalaman seseorang dalam melakukan tugas tertentu secara terus menerus dalam tenggang waktu yang cukup lama dapat meningkatkan kedewasan teknisnya.

Lama kerja berkaitan dengan pengalaman, dimana manusia memperoleh pengetahuan melalui pengalamannya. Apabila seorang bidan mempunyai masa kerja yang cukup lama, maka semakin banyak pengalaman yang diperoleh akan memperlihatkan kinerja yang semakin baik, semakin banyak pengalaman yang diperoleh akan semakin mudah dalam mengatasi persoalan yang dihadapi

\section{d. Hubungan Pendidikan Dengan Kinerja} Bidan Desa Di Desa Tertinggal Dalam Penggerakan Penggerakan Masyarakat di Bidang Kesehatan

Hasil penelitian ini menunjukkan bahwa faktor pendidikan mempunyai nilai POR = 4,45 yang artinya risiko untuk kinerja bidan 
yang rendah pada kelompok pendidikan D3 kebidanan adalah 4,45 kali lebih besar dibandingkan kelompok pendidikan D4 Kebidanan. Secara statistik hubungan ini bermakna dengan nilai $\mathrm{p}$ sebesar $<0,001$ pada tingkat kepercayaan 95\%.

Menurut Crow \& Crow pendidikan adalah proses pengalaman yang memberikan pengertian, pandangan (insight) dan penyesuaian bagi seseorang yang menyebabkan ia dapat berkembang. ${ }^{6}$ Tingkat atau jenjang pendidikan adalah tahap pendidikan yang ditetapkan berkelanjutan, yang ditetapkan berdasarkan tingkat perkembangan peserta didik, tingkat kerumitan bahan pengajaran dan cara meyajikan pengajaran.

Penelitian yang dilakukan oleh Achmad dan Winarsih, menyatakan bahwa tingkat pendidikan sangat berpengaruh terhadap kinerja yang dijalankan seseorang.

\section{e. Hubungan Lama Kerja Dengan Kinerja} Bidan Desa Di Desa Tertinggal Dalam Penggerakan Penggerakan Masyarakat di Bidang Kesehatan

Hasil penelitian ini menunjukkan bahwa faktor lama kerja mempunyai nilai POR = 2,54 yang artinya risiko untuk kinerja bidan yang rendah pada kelompok lama kerja $<5$ tahun adalah 2,54 kali lebih besar dibandingkan kelompok lama kerja $>5$ tahun. Secara statistik hubungan ini bermakna dengan nilai $\mathrm{p}$ sebesar $<0,001$ pada tingkat kepercayaan $95 \%$.

Lama kerja berhubungan dengan bekal yang sangat baik untuk memperbaiki keinerja seseorang. Lama kerja dapat menggambarkan pengalaman seseorang dalam menguasai bidang tugasnya. Green (1980), mengemukakan bahwa kinerja dapat dipengaruhi oleh faktor predisposisi yang di dalamnya termasuk pengalaman kerja. Pengalaman seseorang dalam melakukan tugas tertentu secara terus menerus dalam tenggang waktu yang cukup lama dapat meningkatkan kedewasan teknisnya.

Lama kerja berkaitan dengan pengalaman, dimana manusia memperoleh pengetahuan melalui pengalamannya. Apabila seorang bidan mempunyai masa kerja yang cukup lama, maka semakin banyak pengalaman yang diperoleh akan memperlihatkan kinerja yang semakin baik, semakin banyak pengalaman yang diperoleh akan semakin mudah dalam mengatasi persoalan yang dihadapi

\section{f. Hubungan Pengetahuan Dengan}

Kinerja Bidan Desa Di Desa Tertinggal

Dalam Penggerakan Penggerakan

\section{Masyarakat di Bidang Kesehatan}

Hasil penelitian ini menunjukkan bahwa faktor pengetahuan mempunyai nilai POR $=$ 2,03 yang artinya risiko untuk kinerja bidan yang rendah pada kelompok pengetahuan rendah adalah 2,03 kali lebih besar 
dibandingkan kelompok pengetahuan tinggi. Secara statistik hubungan ini bermakna dengan nilai $\mathrm{p}$ sebesar 0,004 pada tingkat kepercayaan $95 \%$.

Pengetahuan adalah merupakan hasil dari tahu dan ini terjadi setelah orang melakukan penginderaan suatu objek tertentu. Pengetahuan atau kognitif merupakan domain yang sangat penting untuk terbentuknya tindakan seseorang (over behaviour). Dari penelitian terbukti bahwa sikap dan perilaku yang didasari oleh pengetahuan akan bersifat langgeng. Penelitian dari Rogert mengungkapkan bhwa sebelum orang mengadopsi perilaku baru terjadi proses yang berurutan, yaitu : a) awareness, b) interest, c) evaluation, d) trial, e) adoption. Namun demikian penelitian Rogert menyimpulkan bahwa perubahan perilaku tidak selalu melewati tahap - tahap tersebut.

\section{g. Hubungan Motivasi Dengan} Kinerja Bidan Desa Di Desa Tertinggal Dalam Penggerakan Penggerakan Masyarakat di Bidang Kesehatan

Hasil penelitian ini menunjukkan bahwa faktor motivasi mempunyai nilai $\mathrm{POR}=6,05$ yang artinya risiko untuk kinerja bidan yang rendah pada kelompok motivasi rendah adalah 6,05 kali lebih besar dibandingkan kelompok motivasi tinggi. Secara statistik hubungan ini bermakna dengan nilai $\mathrm{p}$ sebesar $<0,001$ pada tingkat kepercayaan $95 \%$.
Menurut Hasibuan (2005), motivasi merupakan daya penggerak yang menciptakan kegairahan kerja seseorang, agar mereka mau untuk bekerja sama, kerja secara efektif dan terintegrasi dengan segala kemampuannya untuk mencapai kepuasan. Artinya, bila motivasi bidan desa di desa tertinggal daam penggerakan masyarakat di bidang kesehatan rendah, maka peluang untuk kinerja tinggi pun rendah.

h. Hubungan Imbalan Dengan Kinerja Bidan Desa Di Desa Tertinggal Dalam Penggerakan Penggerakan Masyarakat di Bidang Kesehatan

Hasil penelitian ini menunjukkan bahwa faktor imbalan mempunyai nilai $\mathrm{POR}=3,81$ yang artinya risiko untuk kinerja bidan yang rendah pada kelompok penghargaan yang rendah adalah 3,81 kali lebih besar dibandingkan kelompok imbalan yang tinggi. Secara statistik hubungan ini bermakna dengan nilai $\mathrm{p}$ sebesar $<0,001$ pada tingkat kepercayaan $95 \%$.

Imbalan/penghargaan sebagai sesuatu yang diberikan oleh atasan kepada karyawan setelah mereka mennjukkan kemampuan, keahlian dan usahanya kepada organisasi tempat ia bekerja. Imbalan dapat berupa gaji/upah, alih tugas promosi, pujian dan pengakuan.

Kepercayaan dalah suatu prasayarat yang diperlukan dalam memotivasi karyawan untuk mendapatkan kompensasi, jika 
karyawan tidak memercayai bahwa manajemen sungguh - sungguh memberikan imbalan sesuai yang telah dijanjikan, maka tidak ada motivasi dari karyawan untuk bekerja secara efektif.

\section{i. Faktor-Faktor Yang Berpengaruh} Secara Simultan Terhadap Kinerja Bidan Desa Dalam Penggerakan Masyarakat Di Bidang Kesehatan

Berdasarkan tabel 3 analisis multivariabel model akhir regresi logistik ganda, hasilnya menunjukkan bahwa terdapat empat variabel independent yaitu umur, pendidikan, motivasi dan penghargaan yang berpengaruh signifikan dalam menghasilkan kinerja bidan yang tinggi. Selanjutnya model regresi logistik tersebut dapat digunakan untuk memprediksi peluang seorang bidan untuk bekerja dengan kinerja tinggi.

Penjelasannya, pada model akhir regresi logistik ganda, hasil nilai $\mathrm{p}$ dari umur adalah 0,010 dan nilai OR 10,30. Artinya bidan desa di desa tertinggal yang berumur $>35$ tahun berpeluang 10,30 kali lebih besar untuk memiliki kinerja tinggi daripada bidan desa di desa tertinggal yang berumur $\leq 35$ tahun. Beberapa studi meyatakan bahwa umumya pekerja yang berusia dewasa lebih stabil dan tetap produktif dibanding dengan rekan kerjanya yang lebih muda.

Faktor pendidikan nilai p 0,014 dan nilai OR 6,96, artinya bidan desa di desa tertinggal dengan pendidikan lebih tinggi
(DIV) memiliki peluang untuk memiliki kinerja tinggi sebesar 6,96 lebih besar daripada bidan dengan pendidikan DIII. Pendidikan kebidanan terdiri dari pendidikan diploma, pendidikan sarjana, pendidikan profesi dan pendidikan pasca sarjana. Penyelenggaraan pendidikan kebidanan adalah institusi pendidikan tinggi baik pemerintah maupun swasta sesuai dengan kaidah - kaidah yang tercantum dalam Sistem Pendidikan Nasional dan Kepmenkes No. 369 tahun 2007 tentang Standar Profesi Bidan.

Penelitian yang dilakukan oleh Achmad F dan Winarsih, menyatakan bahwa tingkat pendidikan sangat berpengaruh terhadap kinerja yang dijalankan seseorang. Faktor motivasi memiliki nilai $\mathrm{p}$ paling signifikan yaitu 0,001 dan nilai OR 21,87, artinya bidan desa di desa tertinggal yang memiliki motivasi tinggi memiliki peluang 21,87 kali lebih besar untuk memiliki kinerja tinggi daripada bidan desa di desa tertinggal dengan motivasi rendah. Motivasi kerja merupakan suatu kondisi atau energi yang menggerakkan diri karyawan sehingga terarah atau tertuju untuk mencapai tujuan organisasi. Sikap mental karyawan yang ditunjukkan menghadapi situasi kerja tersebut, yang memperkuat motivasi kerjanya untuk memperoleh hasil maksimal. ${ }^{2}$ Berdasarkan pandangan tersebut, maka motivasi dapat diartikan sebagai suatu kekuatan, yang berasal dari dalam maupun dari luar diri seseorang, 
yang mendorong seseorang untuk mencapai tujuan terentu yang telah ditetapkan.

Faktor imbalan masuk ke dalam model akhir berdasarkan analisis regresi logistik ganda dengan nilai p 0,022 dan nilai OR 5,91. Artinya bidan desa di desa tertinggal dengan imbalan tinggi berpeluang 5,91 kali lebih besar untuk memiliki kinerja tinggi dalam penggerakan masyarakat di bidang kesehatan daripada bidan desa dengan imbalan rendah. Imbalan/penghargaan sebagai sesuatu yang diberikan oleh atasan kepada karyawan setelah mereka menunjukkan kemampuan, keahlian dan usahanya kepada organisasi tempat ia bekerja. Imbalan dapat berupa gaji/upah, alih tugas promosi, pujian dan pengakuan. Sehingga dapat memacu seorang karyawan untuk bekerja lebih giat dalam melaksanakan tugasnya.

\section{KESIMPULAN DAN SARAN}

\section{Kesimpulan}

a. Kinerja bidan desa di desa tertinggal dalam penggerakan masyarakat di bidang kesehatan di Kabupaten Garut, memiliki kinerja tinggi sebesar 57,1\%.

b. Terdapat hubungan antara faktor umur, tingkat pendidikan, lama kerja, pengetahuan,motivasi,penghargaan/imbala $\mathrm{n}$ dengan kinerja bidan desa di desa tertinggal dalam penggerakan masyarakat di bidang kesehatan di Kabupaten Garut.

c. Faktor umur, tingkat pendidikan, motivasi dan imbalan/penghargaan berpengaruh terhadap kinerja bidan desa di desa tertinggal dalam penggerakan masyarakat di bidang kesehatan di Kabupaten Garut.

\section{Saran}

Dalam upaya meningkatkan kinerja bidan desa di desa tertinggal dalam penggerakan masyarakat di bidang kesehatan di Kabupaten Garut sesuai yang diharapkan , peneliti menyarankan :

\section{a. Saran Teoritis}

Untuk mengetahui secara mendalam diperlukan penelitian lebih lanjut tentang kinerja bidan desa di desa tertinggal dengan faktor faktor /variabel lain agar bisa mendapat gambaran lebih luas. Bagi peneliti selanjutnya dapat dilakukan penelitian dengan menggunakan metode penelitian lain yang bisa menggali lebih dalam tentang kinerja bidan desa di desa tertinggal.

b. Saran Praktis

Peneliti menyarankan supaya :

1) Semua bidan desa melanjutkan pendidikan ke jenjang yang lebih tinggi dari semula pendidikan Diploma III Kebidanan menjadi minimal pendidikan Diploma IV kebidanan agar bisa menambah wawasan pergaulan dan pengetahuan khususnya dalam hal penggerakan masyarakat.

2) Bidan desa di desa tertinggal agar tinggal di desa tempat tugasnya untuk lebih memudahkan dalam menjalankan tugas khususnya dalam hal penggerakan 
masyarakat dan pelayanan kebidanan sehingga bisa meningkatkan kepercayaan masyarakat terhadap bidan dan diharapkan mampu menambah motivasi bidan dalam menjalankan tugas sebagai bidan desa di desa tertinggal.

1, Program Studi D3 Kebidanan
STIKes Karsa Husada Garut
2, Fakultas Kedokteran Universitas
Padjajaran
3, Fakultas Kedokteran Universitas
Padjajaran
Email : intanrsusilawati@yahoo.com

\section{DAFTAR PUSTAKA}

BAPPEDA Garut, Data Dasar Pengentasan Desa Tertinggal. In: Bappeda, editor. Kabupaten Garut: Bappeda Garut; 2012

BAPPENAS. Kajian Analisis Kesenjangan Antar Wilayah. 2012(Situasi Dan Kondisi Kesehatan Di Daerah Tertinggal).

Creswell JW. Research Design: Pendekatan Kualitatif, Kuantitatif, dan Mixed. Jogjakarta: Pustaka Pelajar; 2009.

F A. Setiawan, Hubungan Tingkat Pendidikan Dan Lama Kerja Perawat Dengan Kinerja Perawat Di RSU Pandan Arang
Kabupaten Boyolali. Berita Ilmu Keperawatan. 2008;1(3):9-15.

Garut DKK. Profil Kesehatan Kabupaten Garut Tahun 2013. In: Garut DKK, editor. Kabupaten Garut: Dinas Kesehatan Kabupaten Garut; 2013.

Garut B, editor. Pengentasan Desa Tertinggal. Garut2012

J. SdPD. Manajemen Sumber Daya Manusia : Dalam Organisasi Publik dan Bisnis. Bandung: Alfabeta; 2011.

Juwendah E, Hapsari H, Renaldy E, Saidah Z. Strategi Pengembangan Daerah Tertinggal di Kabupaten Garut. Sosiohumaniora. 2013;15(2):211-21.

Lestari TRP. Pelayanan Kesehatan Di Daerah Tertinggal, Perbatasan, Dan Kepulauan. Info Singkat. 2013;V(12):9 $-11$.

Prabu MAAA. Evaluasi Kinerja Sumber Daya Manusia. ke-6 C, editor. Bandung: Refika Aditama; 2012.

Rencana Strategis Kementerian Kesehatan Tahun 2010 - 2014, (2010).

Soekidjo N. Ilmu Perilaku Kesehatan. Jakarta: Rineka Cipta; 2010.

Syukri Palutturi N, Nurhamsa Mandak. Determinan Kinerja Bidan Di Puskesmas Tahun 2006. Jurnal Manajemen Pelayanan Masyarakat. 2006;10(4):195-200.

UU Nomor 7 Tahun 2007 Tentang Rencana Pembangunan Jangka Panjang Bidang Kesehatan, 7 (2007). 